\title{
Hand Book of Common Ethiopian Traditional Medicinal Plants: Their Parts and Uses for Human and Animal Treatments
}

\author{
Melaku Tafese Awulachew \\ Ethiopian Institute of Agricultural Research, Addis Ababa, Ethiopia
}

Email address:

melakutafese12@gmail.com

\section{To cite this article:}

Melaku Tafese Awulachew. Hand Book of Common Ethiopian Traditional Medicinal Plants: Their Parts and Uses for Human and Animal Treatments. Journal of Diseases and Medicinal Plants. Vol. 7, No. 3, 2021, pp. 48-60. doi: 10.11648/j.jdmp.20210703.11

Received: June 19, 2020; Accepted: September 3, 2020; Published: August 12, 2021

\begin{abstract}
Medicinal plants are very vital in their uses for medication, besides providing ecological, economic, and cultural services. Every human community responds to the challenge of maintaining health and treating diseases by developing a medical system based on indigenous theories, beliefs and experience that are handed down from generation to generation. Health is a fundamental human right. Access to health care, which includes access to essential drugs, is a prerequisite for realizing that right. Essential drugs play a crucial role in many aspects of health care. However, many people throughout the world cannot obtain the drugs they need, either because they are not available or too expensive, or because there are no adequate facilities or trained professionals to prescribe them. World health organization has estimated that at least one-third of the world's population lack access to essential drugs; in poorer areas of Asia and Africa, this figure may be as high as one-half. Traditional Medicine has been used to fill this gap, particularly in developing countries. In Ethiopia, traditional medicine has always existed and was practiced more than we might think. The aim of this material was to document common medicinal plants used for traditional treatments with their parts, use, ecology, and quality control. The local practitioners provided various traditional medications to their patients' diseases such as stomachaches, asthma, dysentery, malaria, evil eyes, cancer, skin diseases, and headaches and so on. The uses of medicinal plants for human and animal treatments are practiced from time immemorial. Stream/riverbanks, cultivated lands, disturbed sites, bush lands, forested areas and their margins, woodlands, grasslands, and home gardens are major habitats of medicinal plants. Above more, medicinal plants used for traditional medicine play a significant role in the healthcare of the majority of the people in Ethiopia. The major threats to medicinal plants are habitat destruction, urbanization, agricultural expansion, investment, road construction, and deforestation. Because of these, medicinal plants are being declined and lost with their habitats. Community- and research-based conservation mechanisms could be an appropriate approach for mitigating the problems pertinent to the loss of medicinal plants and their habitats and for documenting medicinal plants.
\end{abstract}

Keywords: Medicinal Plants, Herbal Medicine, Their Parts Use for Human and Animal Treatments, Quality Control, Ethiopia

\section{Introduction}

Medicinal plants are very vital in their uses for medication, besides providing ecological, economic, and cultural services. The world primary means of treating diseases and fighting infections have been based on the use of medicinal plants. From ancient times, plants have been rich sources of effective and safe medicines [1]. Globally, about $64 \%$ of the total world population is reliant on traditional medicine for their healthcare needs [2]. According to the World Health Organization (WHO), nearly 3.5 billion people in developing countries including Ethiopia believe in the efficiency of plant remedies and use them regularly [3].

The World Health Organization defines traditional medicine as "health practices, approaches, knowledge and beliefs incorporating plant, animal and mineral based medicines, spiritual therapies, manual techniques and exercises, applied singularly or in combination to treat, 
diagnose and prevent illness and maintain wellbeing" [4]. The use of Traditional Medicine in developed countries is termed as complementary/Altemative Medicine (CAM). The term CAM (sometime referred to as "Non- conventional" or "parallel" medicine) refers to a broad set of health care practices that are not part of a country's own tradition or not integrated into its dominant health care system [5] On the other hand, African Traditional Medicine is defined as the total combination of knowledge and practices, whether explicable or not, used in the diagnosis, prevention or treatment of physical, mental or social diseases and which may rely exclusively on past experience and observation handed down from generation to generation, verbally or in writing [6]. In many developing countries in Asia, Latin America, and Africa (including Ethiopia), it serves to meet the primary health care needs of the people [7]. In Ethiopia, traditional medicine plays an important role in the health care system. It is estimated that more than $80 \%$ of the population relies upon traditional medicine due to cultural acceptance; relatively low cost; and lack of access of modern health facilities [8; 9]. The vast majority of Ethiopia's population lives in rural areas where access to health services is challenging. Moreover, existing health sector resources (health workers, resources, and medicines) are limited. The greatest challenge is to determine how best to narrow the gap between the limited services and the population who needs them [10]. In 2003/2004, it was found that at least $30 \%$ of the population did not have access to formal health services. A major contributing factor of this problem is the severe shortage of doctors and healthcare professionals. The national average physician to population ratio was 1:51042, with over $35 \%$ of the physicians found in three major cities, serving $4.7 \%$ of the total population [11]. In recent years, it has been recognized that traditional medicine plays an important role in health systems. Recognizing its importance, governments of many developing countries have made initiatives towards programs to promote safe and effective traditional medicine practices in the health care sector [12]. Spiritual practices play a large part in the healing process and have been integrated with the knowledge of medicinal plants [13]. This indigenous knowledge has been passed down through generations, but is facing the threat of being lost due to cultural change and declining resources for natural medicinal products [14].

The preservation of traditional practices is not only important in ensuring the continued access to medicine, but also for the preservation of the Ethiopian culture. Above all, the preservation of traditional medicines is vital in reducing the loss of biodiversity and promoting environmental health [14]. In efforts to preserve medicinal plant knowledge, in recent years numerous Ethiopian plants have been validated in a scientific empirical framework through phytochemical analysis and subsequent bioassays. This work aimed to document medicinal plants and their parts commonly used by Ethiopian's for human and animal treatment; above all, the document serve to initiate to led for the formulation and distribution of a number of standardized phyto- pharmaceuticals.

\section{Material and Method}

This handbook is meant to serve as a repository of cultural knowledge, and not a manual for botanical medical practice. These plants should only be used under the advisement of knowledgeable practitioner of traditional medicine. A number of plants have poisonous look-alikes and others are toxic when used improperly or in excess dosage and certain plant medicines have dangerous interactions with pharmaceuticals. The diseases recognized by the Ethiopia include both conditions acknowledged by scientific medicine and unique to their culture. The conditions that are most common and most grave appear to have proportionately more plant cures than those that are minor or rare. Causative factors of disease may also diverge from scientific medical thought such as buda or evil eye and being circled by bats.

\subsection{Biodiversity of Ethiopia}

Ethiopia is located in the Horn of Africa between 3 and $15^{\circ}$ northing, latitude, and 33 and $48^{\circ}$ easting, longitude, and is also comprised of nine national regional states and two administrative states with varied agroecological zones. Since the country is characterized by a wide range of ecological, edaphic, and climatic condition, Ethiopia is also very diverse in its flora composition [15]. The flora of Ethiopia is estimated to contain close to $6500-7000$ species including medicinal plants; of those, $12-19 \%$ are endemic to the country [16]. The medicinal plants have been used for various types of human and animal treatments in the country. According to the research finding in Ethiopia, about $80 \%$ of human population and $90 \%$ of livestock rely on traditional medicine and also, medicinal plants have shown very effective medicinal values for some diseases of humans and livestock [17, 18]. Even due to the trust of communities on medicinal values of traditional medicines, culturally associated traditions, and their relatively low cost, medicinal plants are highly demanded in Ethiopia [18]. Inadequate health centers and shortage of medicines and personnel in clinics might be the other reasons for driving the people of Ethiopia, in general, and the low-income community and the rural people, in particular, to the traditional health centers, whereby increasing the demand of medicinal plants. However, these plants have got little attention regarding the documentation of scientific names, uses, ecology, and conservation in Ethiopia, in particular and world-wise, in general. Moreover, in Ethiopia, traditional medicine is faced with a problem of sustainability and continuity mainly due to the loss of taxa of medicinal plants $[19,20]$ besides having lack of quality control for herbal medicines. The main causes for the loss and decline of diversity of plants in Ethiopia are humanmade factors [21-23]. Habitat destruction and deforestation for commercial timber and forest encroachment for urbanization, investment, agriculture, and other land uses are the major causes of the loss of many thousand hectares of forest that harbor medicinal plants yearly for the past several decades. In addition to these, the medicinal plant materials and associated traditional 
knowledge are being lost due to the lack of systematic conservation, research, proper utilization, and documentation [24]. The knowledge on identifying and managing the medicinal plants with their parts, use, and ecology is mostly associated with local and elder people, who transmitted their knowledge verbally. Such verbal transmissions of knowledge on medicinal plants have thus resulted in eroding and loss of knowledge and the plant materials as well. The quantity and quality of the safety and efficacy data on traditional medicine are also far from sufficient to meet the criteria needed to support its use worldwide [25]. Therefore, assessing and documenting the medicinal plants along with their useful medicinal parts, use, and ecology in Ethiopia, as well as revising the quality control for herbal materials and medicine, are very crucial for giving priority to their conservation and sustainable utilization.

\subsection{Medicinal Plants: Their Parts, Uses, and Ecology Reviewed}

Traditional healers in Ethiopia utilize the herbal resources available in nature for various disease treatments. As reported before, approximately 800 species of the medicinal plants grown in Ethiopia are used for treating about 300 medical conditions [26]. However, based on the present review, the number of medicinal plants and the treatments/medications identified and listed are limited as presented here under section by section.

\subsection{Medicinal Plant Parts Used for Preparation of Traditional Remedies}

The document indicated that the plant parts used for medication preparation by the traditional healers are variables. Healers mostly used fresh specimens from commonly available plants [27] to prepare remedies for their patients; this might be mostly due to the effectiveness of fresh medicinal plant parts in treatment since the contents are not lost before use compared to the dried ones [23]. As also referred from many authors, the traditional healers have harvested leaves, roots, barks, seeds, fruits, stems, flowers, barks, seeds, or latex of medicinal plants to prepare their traditional medicines for their patient treatments. The main reason that many traditional medicine practitioners used the leaf parts compared to others for remedial preparation is due to their accessibility and for preventing them from extinction [27]. In fact, harvesting the root parts of the medicinal plant for preparation of traditional medicines has negative consequences on the existence of the plants themselves in the future. That is why most of the medicinal plants are currently at risk, declining highly due to them using their root parts besides other human pressures.

\section{Results}

\subsection{Herbal Medicine}

Plant materials are used throughout developed and developing countries as home remedies, as over-the-counter drug products, and as raw materials for the pharmaceutical industry, which represent a substantial proportion of the global drug market [28]. Thus, the traditional herbal medicines and their preparations have been widely used for thousands of years in many countries. Therefore, it is so essential to overview here some modern control histological techniques or tests, suitable standards, and practical experiences used for assessing the quality of medicinal materials and their products. Quality control of herbal medicine using histological techniques and pharmaceutical practices is also very vital for avoiding the risks happened on patients and the beliefs in services provided by traditional healers. According to [29], quality control is a phrase that refers to processes involved in maintaining the quality or validity of the manufactured products. However, the quality control of herbal medicine is beyond this, meaning it is the management of medicinal plants and their products during cultivation, identification process of the plant species with their parts and localities (their being free from polluted environment causing diseases), and medicine preparation including its components, medication processes, storage standards, and dosage; all should be taken into account. This means, without proper all-round quality control, there is no assurance that the contents of the herbs contained in the package are the same as what are stated outside the package [29]. Climatic factors (prevailing temperature, rainfall, humidity, altitude of the growing region, light), nutritional factors (nutrients, $\mathrm{pH}$, cation exchange capacity), harvesting factors (age, season, collection time, plant organ), and postharvesting factors (storage hygiene, drying process) are the major factors affecting the contents and composition of medicinal plant raw materials and their products [28, 29]. For these, some of the most important laboratory test methods (histological techniques), common sense, and good pharmaceutical practices are used [28]. Techniques such as thin-layer chromatography and microscopic and electrophoretic techniques are widely used to evaluate the quality of herbal drugs $[25,28,30]$ and the content and quality of meats [31] as well. These techniques and good pharmaceutical practices are also used to support the development of national standards based on local market conditions, with due regard to existing national legislation and national and regional norms [28]. Therefore, improved and currently available pharmaceutical analytical methods led to improvements in harvesting schedules, cultivation techniques, storage, product purity, and activity and stability of active compounds [29]. Among others, thin-layer chromatography, macroscopic and microscopic examinations, gas chromatography and volatile components, and electrophoretic techniques $[25 ; 28]$ are the most important quality control methods for medicinal plant materials.

\subsection{Medicinal Plants}

There are various forms of medicinal plants including trees, shrubs, climbers, and herbs; of those herbal medicinal plants are dominantly used for different human and animal treatments in Ethiopia. These plants are collected mainly from riverbanks, cultivated areas, bush lands, forest, woodlands, and grasslands, among others. They are used for treatments of stomachaches, dysentery, diarrhea, asthma, 
cancer, evil eyes, earaches, sores of throat and gum, cough, and so on. For such treatments, these medicinal plants have specific parts used for treatment; most of them are leaves and roots. As referred from the revised documents for this review, the habitat preference of medicinal plants varied from place to place are illustrated in (Tables 1 and 2).

Table 1. List of reviewed Ethiopian medicinal plants used for various traditional disease treatments with their parts and ecology/ habitat.

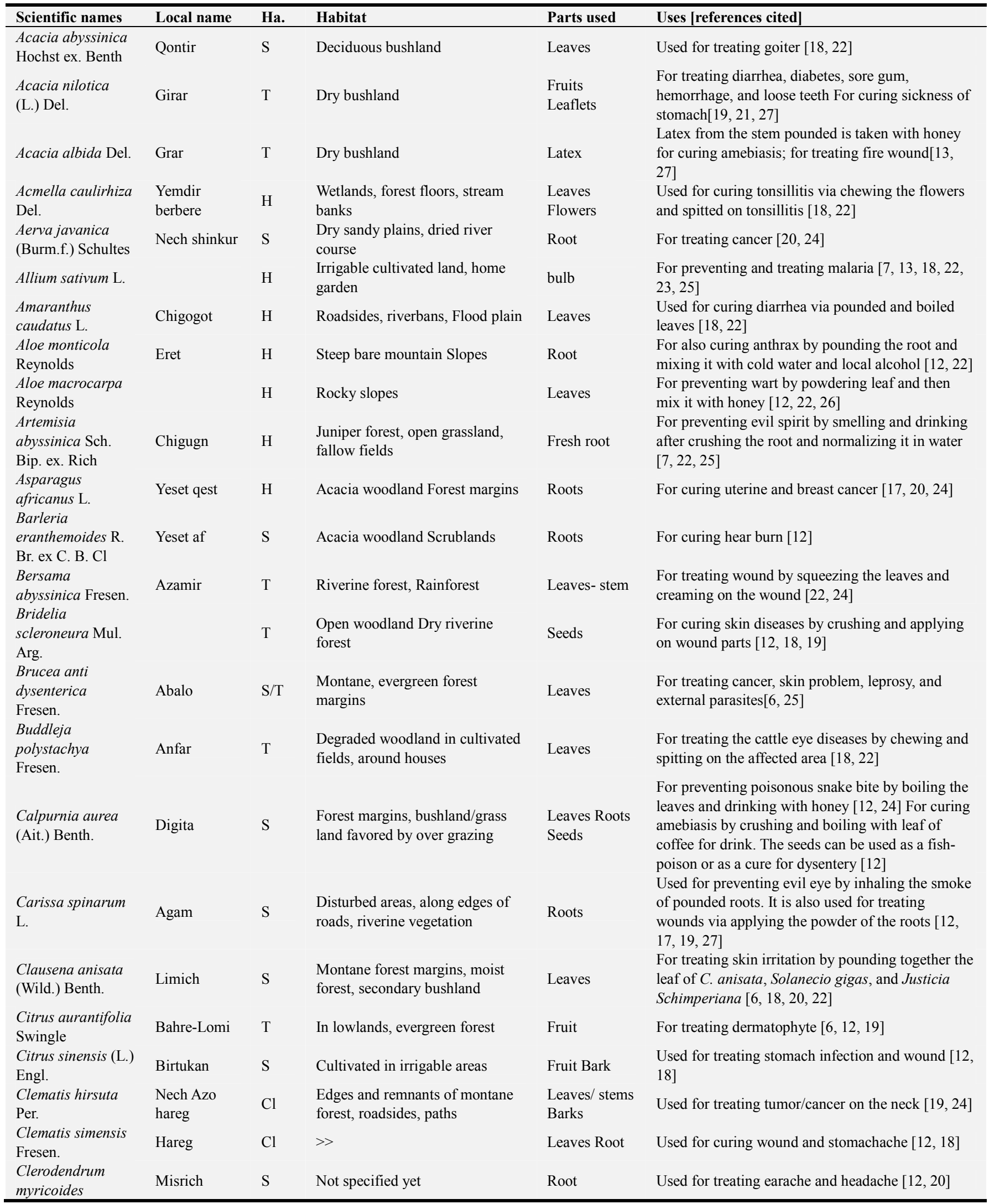




\begin{tabular}{|c|c|c|c|c|c|}
\hline Scientific names & Local name & Ha. & Habitat & Parts used & Uses [references cited] \\
\hline \multicolumn{6}{|l|}{ (Hochs) } \\
\hline Coffee Arabica L. & Buna & $\mathrm{S}$ & In shaded coffee plantations & Seeds & $\begin{array}{l}\text { For curing diarrhea by pounding and mixing with } \\
\text { honey }[6,12,18]\end{array}$ \\
\hline $\begin{array}{l}\text { Cordia africana } \\
\text { Lam. }\end{array}$ & Wanza & $\mathrm{T}$ & $\begin{array}{l}\text { Moist evergreen forest, riverine } \\
\text { vegetation, woodland, grassland }\end{array}$ & Roots & $\begin{array}{l}\text { For curing itching via applying the powder of the } \\
\text { root on the area }[6,12,13,18,19]\end{array}$ \\
\hline $\begin{array}{l}\text { Crinum } \\
\text { abyssinicum }\end{array}$ & Yejb shinkurt & $\mathrm{H}$ & $\begin{array}{l}\text { Waterlogged valley grasslands, } \\
\text { swampy or along stream banks, } \\
\text { fallow fields }\end{array}$ & Leaves & $\begin{array}{l}\text { Used as treatment of tumor in general }[13,20,24 \text {, } \\
25]\end{array}$ \\
\hline $\begin{array}{l}\text { Croton } \\
\text { macrostachyus } \\
\text { Hochst. ex Del. }\end{array}$ & Bisana & $\mathrm{T}$ & $\begin{array}{l}\text { Forest margin, edges of roads, } \\
\text { disturbed areas, woodland }\end{array}$ & Bark & $\begin{array}{l}\text { For curing splenomegaly and gonorrhea }[12,17 \text {, } \\
18,20,22,25]\end{array}$ \\
\hline Croton zambesicus & Bisana & $\mathrm{T}$ & $\begin{array}{l}\text { Stony streambeds, within broad- } \\
\text { leaved deciduous woodland }\end{array}$ & Bark & Used for treating mental disturbance $[21,27]$ \\
\hline
\end{tabular}

Table 1. Continued.

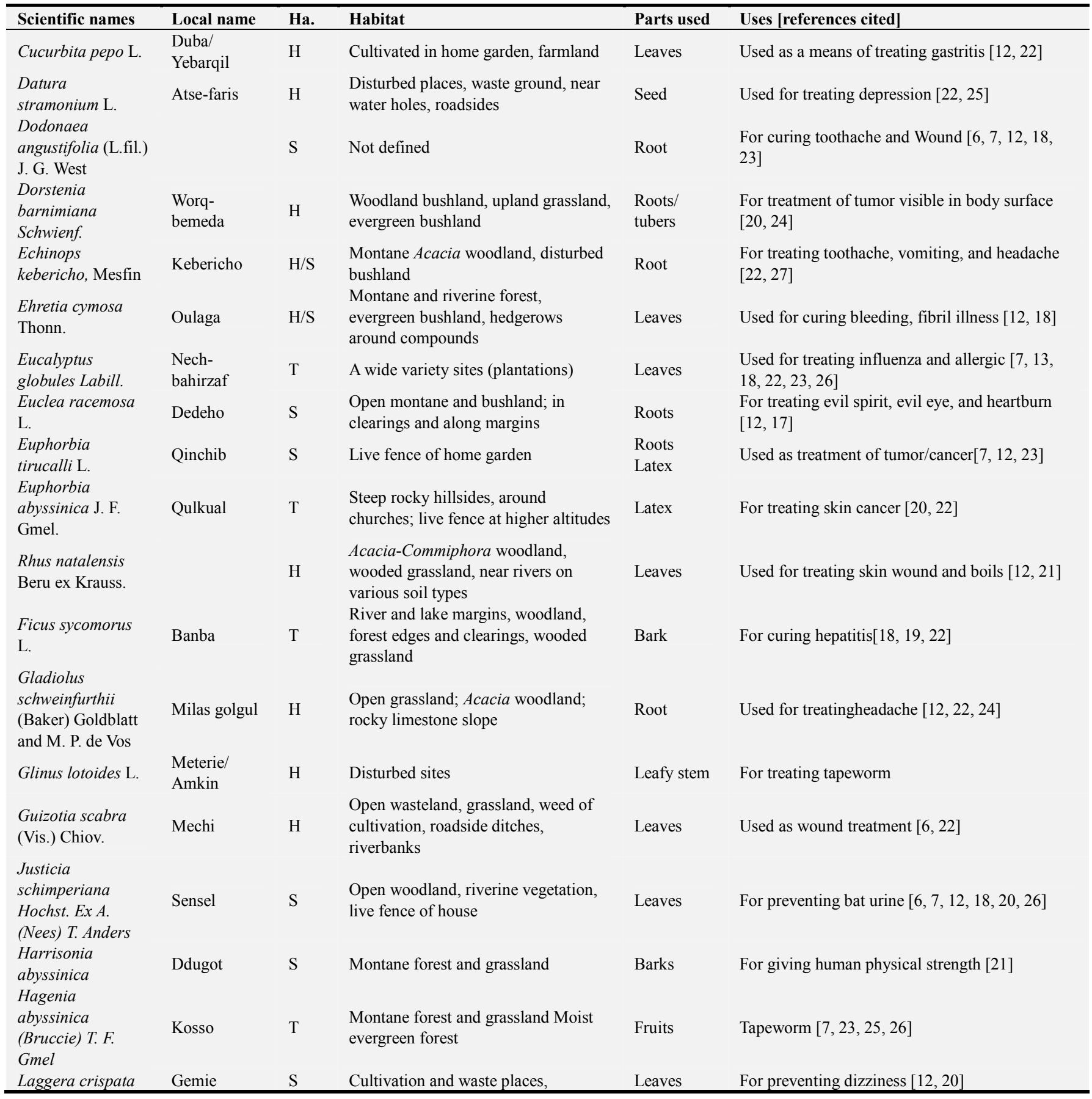




\begin{tabular}{|c|c|c|c|c|c|}
\hline Scientific names & Local name & Ha. & Habitat & Parts used & Uses [references cited] \\
\hline (Vahl.) & & & grassland, riverbanks & & \\
\hline $\begin{array}{l}\text { Maesa lanceolata } \\
\text { Forssk }\end{array}$ & & $\mathrm{T} / \mathrm{S}$ & $\begin{array}{l}\text { Gallery forest, margin of evergreen } \\
\text { forest, along river banks and streams, } \\
\text { open woodland and valleys }\end{array}$ & Bark & For curing elephantiasis $[6,18,26]$ \\
\hline $\begin{array}{l}\text { Malva verticillata } \\
\mathrm{L} \text {. }\end{array}$ & Lut & $\mathrm{H}$ & $\begin{array}{l}\text { Paths and clearings in upland forest, } \\
\text { upland grassland, cultivated areas near } \\
\text { houses }\end{array}$ & Root & For curing cancer/ tumor $[6,18,24,25]$ \\
\hline $\begin{array}{l}\text { Mimusops kummel } \\
\text { A. DC. }\end{array}$ & Safa/kummel & $\mathrm{T} / \mathrm{S}$ & $\begin{array}{l}\text { In gullies, in riverine forest, in } \\
\text { riparian woodland, in woody } \\
\text { vegetation on lake shores }\end{array}$ & Root & Used for preventing lung cancer $[12,18]$ \\
\hline $\begin{array}{l}\text { Moringa } \\
\text { stenopetala (E. G. } \\
\text { Baker) Cufod. }\end{array}$ & Shiferaw & $\mathrm{T}$ & $\begin{array}{l}\text { Cultivated in terraced fields, gardens, } \\
\text { small towns, in riverine and woodland }\end{array}$ & Root & Used for asthma relief $[7,12,21]$ \\
\hline Musa sapientum $\mathrm{L}$. & Koba & $\mathrm{H}$ & $\begin{array}{l}\text { Cultivated on large irrigated farms } \\
\text { and in house gardens }\end{array}$ & Bulb & It is taken as an abortion medicine $[19,21]$ \\
\hline $\begin{array}{l}\text { Nicotiana tabacum } \\
\text { L. }\end{array}$ & Timbaho & $\mathrm{H}$ & $\begin{array}{l}\text { Cultivated in villages, home gardens, } \\
\text { tobacco farms }\end{array}$ & Leaves & For treating snakebite $[6,12,18]$ \\
\hline Nigella sativa $\mathrm{L}$. & Tikur azmud & $\mathrm{H}$ & $\begin{array}{l}\text { Cultivated in homesteads, in fields; } \\
\text { growing in wild }\end{array}$ & Seed & Used as treatment of headache $[18,22]$ \\
\hline $\begin{array}{l}\text { Ocimum } \\
\text { lamiifolium } \\
\text { Hochst. ex. Benth. }\end{array}$ & Damakesie & $\mathrm{S}$ & $\begin{array}{l}\text { Acacia-Commiphora bush-and } \\
\text { woodland, limestone slopes, home } \\
\text { gardens }\end{array}$ & Leaves & Fibril illness $[7,12,18,20,22]$ \\
\hline Olea europaea $\mathrm{L}$. & Woira & $\mathrm{T}$ & $\begin{array}{l}\text { Home garden, monasteries and } \\
\text { churches, woody vegetation }\end{array}$ & $\begin{array}{l}\text { Leaves/ } \\
\text { roots }\end{array}$ & $\begin{array}{l}\text { For curing dysentery, wound stomachache, bone } \\
\text { TB }[6,12,17,18,20,26]\end{array}$ \\
\hline $\begin{array}{l}\text { Opuntia ficus- } \\
\text { indica (L.) Miller }\end{array}$ & $\begin{array}{l}\text { Yebereha } \\
\text { qulkual }\end{array}$ & $\mathrm{S}$ & $\begin{array}{l}\text { Disturbed areas, degraded areas, live } \\
\text { fence of houses }\end{array}$ & Leaves & For killing malaria vectors $[22,25]$ \\
\hline $\begin{array}{l}\text { Plumbago } \\
\text { zeylanica } \mathrm{L} \text {. }\end{array}$ & Amira & $\mathrm{H}$ & $\begin{array}{l}\text { Disturbed habitats by roads and paths, } \\
\text { bush land, woodland, savannah }\end{array}$ & Root & $\begin{array}{l}\text { For preventing gonorrhea and hemorrhoids as } \\
\text { well as for toothache }[12,20,22]\end{array}$ \\
\hline $\begin{array}{l}\text { Verbascum } \\
\text { sinaiticum Benth. }\end{array}$ & & $\mathrm{H}$ & Disturbed sites & $\begin{array}{l}\text { Root/ } \\
\text { leaves }\end{array}$ & $\begin{array}{l}\text { For treating heart disease, cancer, } \\
\text { trypanosomiasis }[6,20,27]\end{array}$ \\
\hline $\begin{array}{l}\text { Premna schimperi } \\
\text { Engl. }\end{array}$ & Chocho & $S$ & $\begin{array}{l}\text { Degraded and secondary forests, } \\
\text { grassy meadows and along paths in } \\
\text { forests }\end{array}$ & $\begin{array}{l}\text { Root } \\
\text { Leaves }\end{array}$ & $\begin{array}{l}\text { Used for treating Mastitis Used for preventing } \\
\text { boils }[12,18]\end{array}$ \\
\hline Solanum Nigrum & Embuay & $\mathrm{H}$ & $\begin{array}{l}\text { In cultivation and ruderal areas, on } \\
\text { road-, hill-, river- or streamsides; in } \\
\text { bushland areas }\end{array}$ & $\begin{array}{l}\text { Leaves } \\
\text { roots, stems }\end{array}$ & $\begin{array}{l}\text { Leaf, root, and stalk are used for cancerous sores } \\
\text { and wound treatments. Stems eaten as pot herb } \\
\text { for virility in men and for Dysmenorrhea in } \\
\text { females, for dysentery, and sore throat }[21,24]\end{array}$ \\
\hline $\begin{array}{l}\text { Solanum incanum } \\
\text { L. }\end{array}$ & Tikur awud & $\mathrm{H}$ & $\begin{array}{l}\text { Cultivated and riverine gallery forest, } \\
\text { disturbed Habitats }\end{array}$ & $\begin{array}{l}\text { Leaves/ } \\
\text { roots }\end{array}$ & $\begin{array}{l}\text { Used for curing bleeding, menstruation, } \\
\text { amebiasis }[12,17-20]\end{array}$ \\
\hline $\begin{array}{l}\text { Stephania } \\
\text { abyssinica (Dill. } \\
\text { And A. Rich.) } \\
\text { Walp.(Etse Eyesus, } \\
\text { Nech- Hareg) }\end{array}$ & Yayit hareg & $\mathrm{Cl}$ & $\begin{array}{l}\text { In thickets bordering forest margins, } \\
\text { hillsides, cultivated fields, in clearings }\end{array}$ & Root & $\begin{array}{l}\text { For treating external tumor/ cancer and } \\
\text { stomachache }[6,12,8,24,25]\end{array}$ \\
\hline $\begin{array}{l}\text { Stereospermum } \\
\text { kunthianum Cham. }\end{array}$ & Arziniya & $\mathrm{S} / \mathrm{T}$ & $\begin{array}{l}\text { Open woodland and savanna, } \\
\text { widespread in tropical Africa }\end{array}$ & Bark & $\begin{array}{l}\text { Used for treating kidney via drinking the juice } \\
\text { crushed from bark }[12,13,19]\end{array}$ \\
\hline $\begin{array}{l}\text { Tamarindus indica } \\
\text { L. }\end{array}$ & Humer/Roqa & $\mathrm{T}$ & $\begin{array}{l}\text { Grassland, woodland Combretum } \\
\text { bushland, riparian }\end{array}$ & Fruit & $\begin{array}{l}\text { Used for curing stomachache; it is also used for } \\
\text { treating bile and intestinal worm using the fruit } \\
\text { juice with hot water in the morning before } \\
\text { breakfast }[12,19]\end{array}$ \\
\hline $\begin{array}{l}\text { Thunbergia } \\
\text { ruspolii Lindau }\end{array}$ & Marte & $\mathrm{H}$ & $\begin{array}{l}\text { CombretumTerminalia woodland, } \\
\text { grassland, wooded grassland, } \\
\text { evergreen forest, seasonally } \\
\text { waterlogged }\end{array}$ & $\begin{array}{l}\text { Not } \\
\text { reported }\end{array}$ & For curing poisonous snakebite [21] \\
\hline $\begin{array}{l}\text { Thymus capitatus } \\
\text { (L.) Link }\end{array}$ & Tosign & $\mathrm{H}$ & Not reported & Leaves & $\begin{array}{l}\text { For curing stomach diseases, cough, and asthma } \\
{[21,25]}\end{array}$ \\
\hline $\begin{array}{l}\text { Tragia cordata } \\
\text { Michx. }\end{array}$ & Alebilabet & $\mathrm{H}$ & Among open rock Bushlands & Root & $\begin{array}{l}\text { For treating urinary tract and external parasite } \\
{[12,18,19]}\end{array}$ \\
\hline $\begin{array}{l}\text { Tribulus terrestris } \\
\text { L. }\end{array}$ & Kurnchit & $\mathrm{H}$ & $\begin{array}{l}\text { Open and disturbed places, often on } \\
\text { sandy soils }\end{array}$ & $\begin{array}{l}\text { Stem Fruit } \\
\text { Seed }\end{array}$ & $\begin{array}{l}\text { For curing scabrous skin Diseases; For } \\
\text { congestion, headache, hepatitis, liver, vertigo, } \\
\text { stomatitis, kidneys, liver, and vision; For treating } \\
\text { anemia, hemorrhoid coughs, fluxes, and } \\
\text { stomatitis [21] }\end{array}$ \\
\hline Urtica pilulifera $\mathrm{L}$. & Sama & $\mathrm{H}$ & Unknown & Leaves & $\begin{array}{l}\text { For curing sore joints by mixing the plant juice } \\
\text { with oil; provide cure for rheumatism and } \\
\text { hemorrhage }[18,21]\end{array}$ \\
\hline Vernonia & Girawa & $\mathrm{S}$ & Bush/woodland, forest habitats, home & Leaves & For preventing headache and intestinal worm and \\
\hline
\end{tabular}




\begin{tabular}{|c|c|c|c|c|c|}
\hline Scientific names & Local name & На. & Habitat & Parts used & Uses [references cited] \\
\hline amygdalina Del. & & & gardens & & $\begin{array}{l}\text { for treating tumor/cancer in general }[6,7,12,18 \text {, } \\
20,22,24,26,27]\end{array}$ \\
\hline $\begin{array}{l}\text { Xanthium } \\
\text { strumarium } \mathrm{L} .\end{array}$ & Deha nikel & $\mathrm{H}$ & $\begin{array}{l}\text { Wet forest margins, in riverine } \\
\text { vegetation by streamside }\end{array}$ & Leaves & Used for treating dandruff $[12,27]$ \\
\hline $\begin{array}{l}\text { Ximenia } \\
\text { americana } \mathrm{L} .\end{array}$ & Enkoy & $\mathrm{S}$ & $\begin{array}{l}\text { Acacia woodland, Acacia-Ballanites, } \\
\text { woodland, Combretum Terminalia, } \\
\text { wooded grassland }\end{array}$ & $\begin{array}{l}\text { Fruit } \\
\text { Kernel } \\
\text { Root }\end{array}$ & $\begin{array}{l}\text { Oil from the fruit kernel is applied to fresh } \\
\text { wounds to prevent infections and also used by } \\
\text { some people, who have their ears or lips pierced } \\
\text { Used for treating stomachache and tonsillitis [ } 6 \text {, } \\
12,19,20]\end{array}$ \\
\hline $\begin{array}{l}\text { Warburgia } \\
\text { ugandensis } \\
\text { Sprague }\end{array}$ & & $\mathrm{T}$ & $\begin{array}{l}\text { Transitional montane forest, adjacent } \\
\text { woodland }\end{array}$ & Stem & Used for treating boils and cough $[12,17]$ \\
\hline $\begin{array}{l}\text { Withania } \\
\text { somnifera } \text { L. } \\
\text { Dunal }\end{array}$ & Gizawa & $\mathrm{S}$ & $\begin{array}{l}\text { In cultivations, disturbed places in the } \\
\text { highlands, on lake shores, along } \\
\text { riverbanks in disturbed places in open } \\
\text { woodland }\end{array}$ & Leaves & Used for treating malaria $[12,13,17]$ \\
\hline $\begin{array}{l}\text { Ziziphus spina- } \\
\text { christi (L.) Desf }\end{array}$ & Qurqura & $\mathrm{T}$ & $\begin{array}{l}\text { Wooded grassland, along dry } \\
\text { riverbeds, edges of cultivations and } \\
\text { home gardens }\end{array}$ & Fruits & $\begin{array}{l}\text { Used for treatments of stomachache, tonic, for } \\
\text { tooth aches, and tumors }[21,13]\end{array}$ \\
\hline Carica papaya & Papaya & $\mathrm{S} / \mathrm{H}$ & Home garden & Seed & $\begin{array}{l}\text { used to treat Amoebic dysentery and abortion, for } \\
\text { Amoebic dysentery: chew } 7 \text { seeds three times a } \\
\text { day and for Abortion: maceration of young leaves } \\
\text { in cold water [32]. }\end{array}$ \\
\hline $\begin{array}{l}\text { Millettia } \\
\text { ferruginea }\end{array}$ & Birbira & $\mathrm{T}$ & $\begin{array}{l}\text { Home garden, monasteries and } \\
\text { churches, woody vegetation }\end{array}$ & Pod & $\begin{array}{l}\text { used to treat Abortion; cold water maceration of } \\
\text { pod, drink to induce abortion (N/A) }\end{array}$ \\
\hline
\end{tabular}

Table 2. List of reviewed Ethiopian Medicinal plants (including; plant name, family, local name, of people, growth form, plant part, used against, administration, mixed with and voucher number) of the peoples of Amhara, Shinasha, and Agew-Awi) [33].

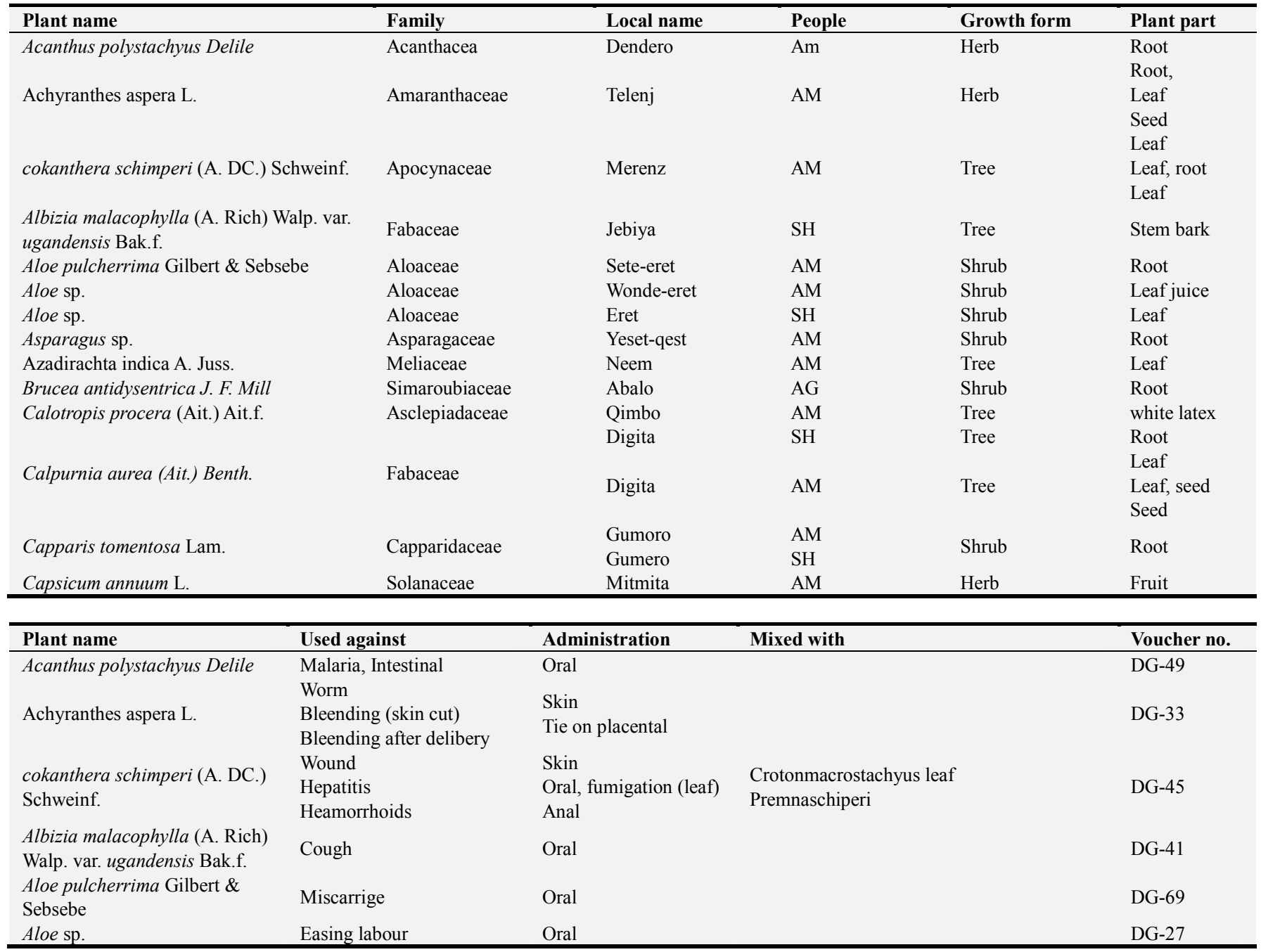




\begin{tabular}{|c|c|c|c|c|}
\hline Plant name & Used against & Administration & Mixed with & Voucher no. \\
\hline Aloe sp. & Malaria & Oral & \multirow[b]{2}{*}{$\begin{array}{l}\text { Carissa spinarum (root); } \\
\text { clerodendrummyricoides (root); } \\
\text { capparistomentosa (root); croton } \\
\text { macrostachyus; carica; papaya capparis } \\
\text { tomentosa (root). }\end{array}$} & DG-56 \\
\hline Asparagus sp. & Bleeding after delibery & Fumigation & & DG-10 \\
\hline Azadirachta indica A. Juss. & Malaria & & \multirow{9}{*}{$\begin{array}{l}\text { carissa spinarum (root); clerodendrum } \\
\text { myricoides (root); capparis tomentosa (root). } \\
\text { Oral }\end{array}$} & DG-18 \\
\hline Brucea antidysentrica J. F. Mill & Evil eye & Tie around nake & & DG-55 \\
\hline Calotropis procera (Ait.) Ait.f. & Haemorrhoids & Anal & & DG-51 \\
\hline \multirow{4}{*}{ Calpurnia aurea (Ait.) Benth. } & Amoebiasis, giardiasis & Oral & & DG-42 \\
\hline & Malaria & Oral & & \multirow{3}{*}{ DG-42 } \\
\hline & Diarrhoea, rabies, diabates & Oral & & \\
\hline & Hypertension & Oral & & \\
\hline Capparis tomentosa Lam. & Bleeding after delibery & Fumigation & & DG-53 \\
\hline Capsicum annuит $\mathrm{L}$. & Malaria & Malaria & & \\
\hline
\end{tabular}

NB: Ha, habits; T, tree; S, shrub; H, herbs; Cl, climbers; T/S, shrubs/trees; H/S, herbs/shrubs.

Table 2. Continued.

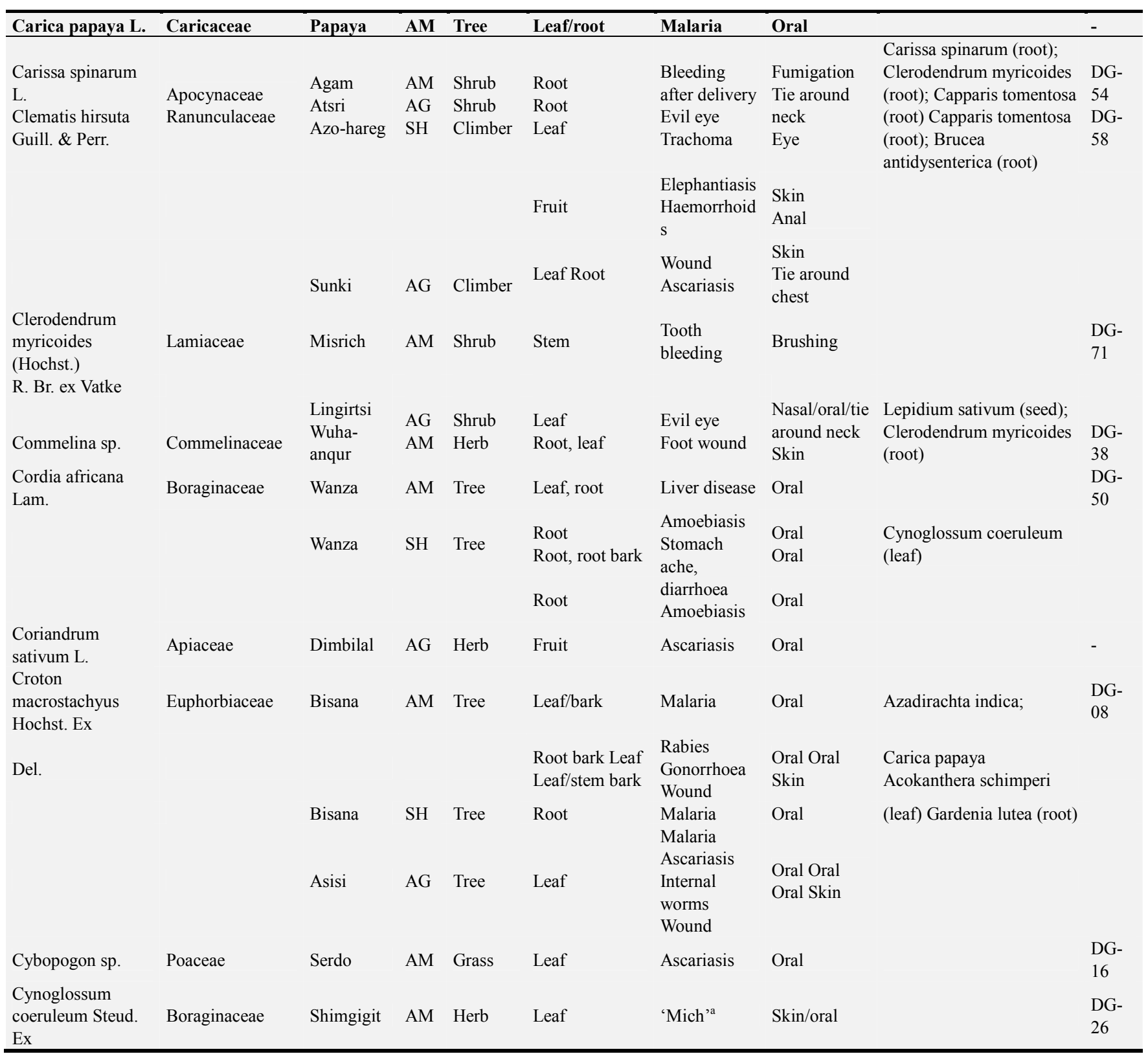




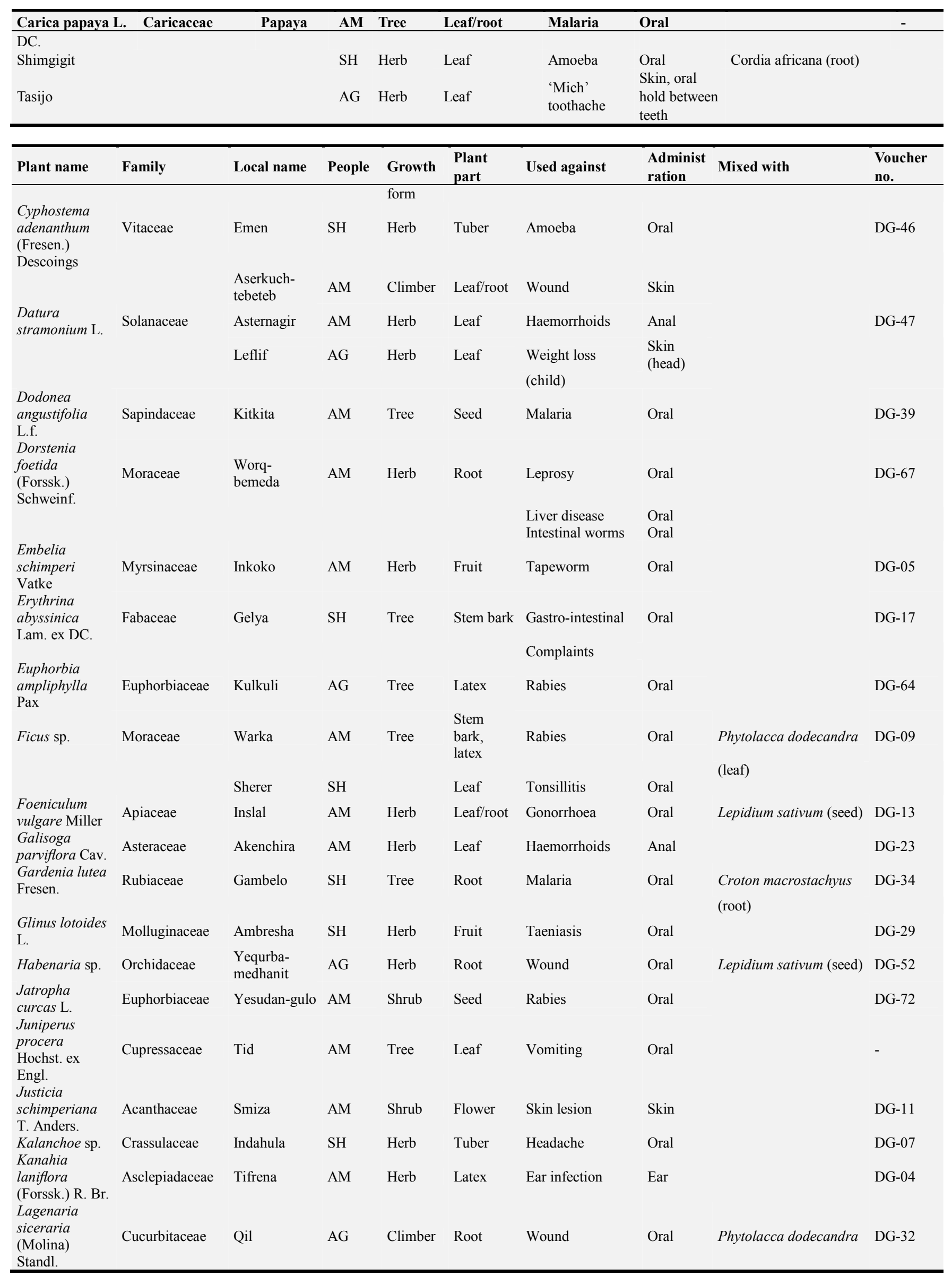




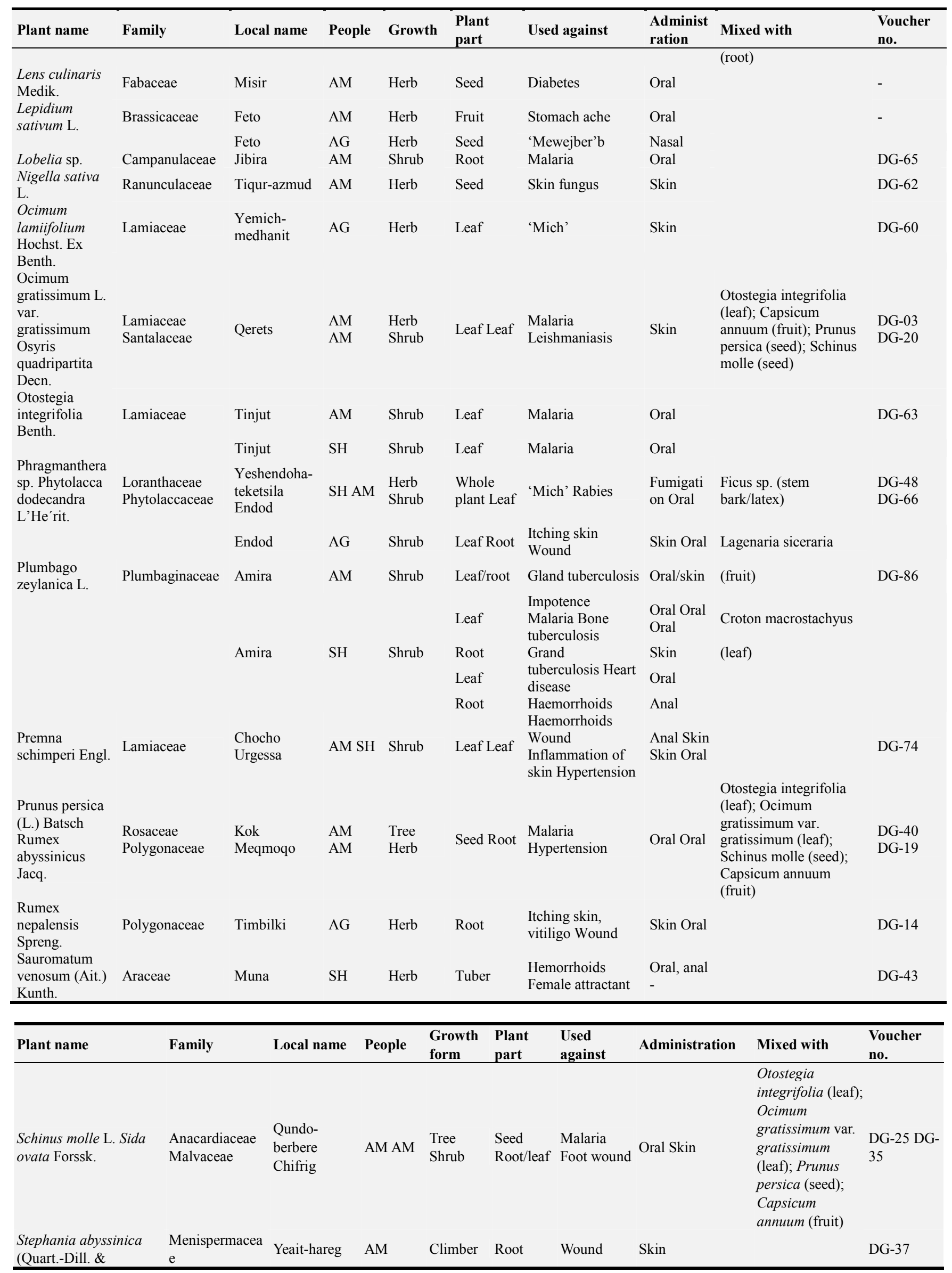




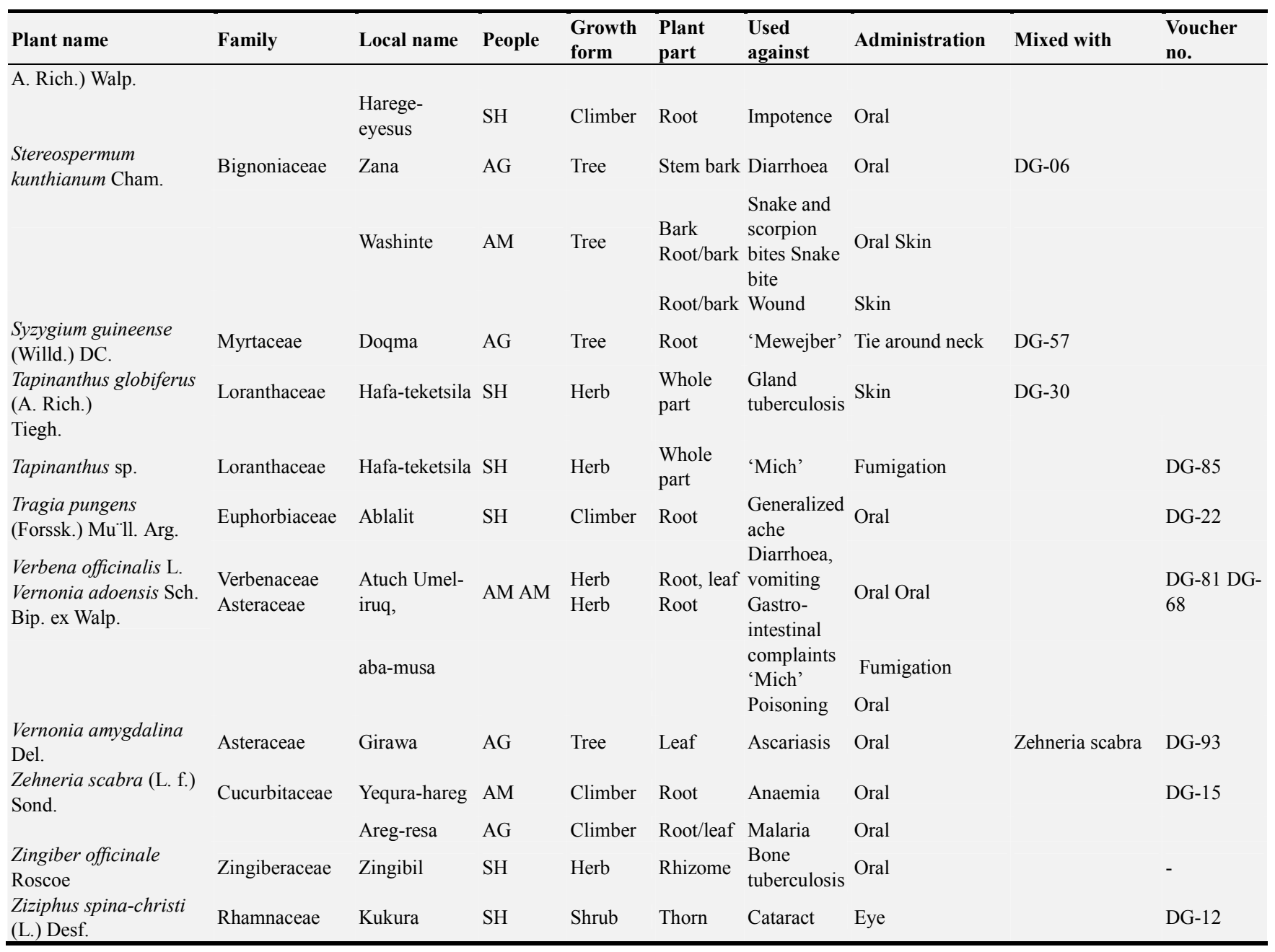

NB: AM, Amhara; SH, Shinasha and AW, Agew-Awi.

Results of the document have indicated that traditional medicine is still playing a significant role in meeting the basic health- care need of the peoples of the Ethiopia in different part of the region. [34, 35] Most reme- dies in the study area were found to be prepared from a single plant. Other studies in other parts of the country, however, indicated the common use of concoctions because of the wider belief of the synergic effect of one plant over the other [35]. Informant consensus results could be useful in priori- tising medicinal plants for further studies. pharmacologically effective reme- dies are expected to have relatively greater informant consensus[36]. Accordingly, the plants Croton macrostachyus, Cynoglossum coeruleum and Zehneria scabra which were found to have relatively higher informants consensus values for being used as remedies against malaria, 'mich', and malaria, respectively, deserve further investigation. Methanol and chloroform extracts of the fruits of Croton macrostachyus were reported to have strong in vitro activity against the malaria parasite, Plasmodium falciparum [37]. The plant was also reported to have molluscicidal properties [38, 39]. Phytochemical studies revealed that Croton macrostachyus contains active substances such as crotin and crotepoxide resins. Calpurnia aurea was also reported to have active principles such as calpurnin and tannin [40]. In situ and ex situ conservation measures are required to be taken on those medicinal plants which are found to be scarce in the document area but still are harvested from the wild only. Con- servation priority should also be given to multipurpose plants (plants with more diversified medicinal uses) as this could indicate high intensity of harvest, which could lead to over- exploitation.

\section{Discussion}

Medicinal plants revised the local communities could be able to treat different disease types. The disease types treated by these various medicinal plants were skin disease, gonorrhea, diarrhea, wound, tapeworm, snake bites, stomachache, headache, evil eye, heartburn, cancer/tumor, and malaria. Particularly, most of the patients (who come from rural areas) with their perspective disease types have been treated by traditional heal- ers, before coming to clinics and/or hospitals located far away by many kilometers from their residential areas. The disease types most frequently treated by traditional medications (traditional healers) provided by those medicinal plants were stomachaches, wounds, cancers/tumors, skin diseases, headaches, toothaches, and coughs and diarrhea, which took the first, 
second, third, fourth, fifth, sixth, and seventh ranks, respectively, although the majority of disease types were frequently treated less than four times, ranging from one to three times. This also points out that one medicinal plant species can be used for treating more than one disease types. Because of this, medicinal plants are very vital in providing traditional medi- cines, prepared by local healers, and thereby used for treating and curing different types of diseases that affected the local communities, where they occurred. In addition to these contributions pertinent to traditional medications and cultural values, the individual medicinal plants could provide regulating, provision- ing, and supporting services. For instance, they could provide regulating services via regulating soil erosion, climate change, disease, pollution, and pollination; they also provide provisioning services such as fuel wood, timber for house construction, food (fruits, honey), and fodder and shelter for wild animals. Hence, almost all of the medicinal plants are multipurpose species, providing more than one benefits.

Table 3. Disease type categories and their rank based on their frequency being treated by different medicinal plant species (as described in Table 1).

\begin{tabular}{lll}
\hline No. of disease type & Frequency of treatments \\
\hline 1 (Stomachaches) & 12 \\
1 (Wounds) & 11 \\
1 (Cancer/tumor) & 10 \\
1 (Skin diseases) & 7 \\
1 (Headaches) & 6 \\
1 (Toothaches) & 5 \\
2 (Cough, diarrhea) & 3 (each) \\
8 (Tonsillitis, malaria, evil eye, snakebites, dysentery, boils, throat sore, intestinal worms) & 3 (each) \\
10 (Earache, amebiasis, urinary tract, heartburn, external parasites, fibril illness, kidney, liver, hemorrhoids, tapeworms) & 2 (each) \\
43 (Elephantiasis, asthma, eye diseases, diabetes, anthrax, leprosy, etc.) & 1 (each) \\
\hline
\end{tabular}

\section{Conclusion}

Traditional medicine plays a significant role in the healthcare of the majority of the people in developing countries and medicinal plants provide valuable contribution to this practice. However, the vegetative resources that are unique to the country, particularly used for medication, are dwindling due to continuous exploitation and pressure on the limited resources. Hence, conservation priority should be given to such medicinal plants and their habitats besides the knowledge of traditional practice of medication via designing appropriate strategies, particularly in the rural areas of the country, where there are less accessibility to clinics and hospitals with their medicines and health experts (doctors). Community- and research-based conservation mechanisms could be an appropriate approach for mitigating the problems pertinent to the loss of medicinal plants and their habitats and for documenting medicinal plants and the knowledge of traditional healers on how to prepare and provide the traditional medication to their patients. Medicinal plants should be multiplied through medicinal gardens, proper handling practices, and scientific development.

\section{References}

[1] Russell SJ, Karunaratne NS, Mahindapala RT. Rapid inventory of wild medicinal plant populations in Sri Lanka. Journal of Biological Conservation. 2006; 132 (4): 22-32.

[2] Phondani PC, Bhatt ID, Negi VS, Kothyari BP, Batt A, Maikhuri RK. Promoting medicinal plants cultivation as a tool for biodiversity conservation and livelihood enhancement in Indian Himalaya. Journal of Asia-Pacific Biodiversity. 2016; 9 (1): $39-46$.
[3] WHO (World Health Organization). Fact Sheet. Family, Body, Sexuality and Health. Geneva: World Health Organization; 2003. pp. 205-219. Available from: http:// books.google.com.et/books.pdf [Accessed: 11 March 2019].

[4] Oliver-Bever B. Medicinal Plants in Tropical West Africa, Cambridge University Press, Cambridge.

[5] Desta, B. Ethiopian traditional herbal drugs Part II: Antimicrobial activity of 63 medicinal plants, Journal of Ethnopharmacology 1986; 39, 129-139.

[6] WHO. Legal Status of Traditional Medicine and Complementary/Alternative Medicine: A World Wide Review. Geneva 2001

[7] WHO. Fact Sheet, Traditional Medicine, Geneva, May 2003.

[8] Lambert J. Ethiopia: Traditional medicine and the bridge to better health. World Bank. http://www.worldbank.org/afr/ik/default.htm.

[9] Central Statistical Authority and ORC Macro Ethiopia Demographic and Health Survey 2000. Addis Ababa Ethiopia and Calverton, Maryland, USA, May 2001.

[10] Transitional Government of Ethiopia Health Sector Strategy. Addis Ababa, April 1995.

[11] Federal Democratic Republic of Ethiopia Ministry of Health. Health and Health Related Indicators 2003/04. Addis Ababa, December 2004.

[12] WHO. National Policy on Traditional Medicine and regulation of Herbal medicines, Report of a WHO Global Survey, Geneva, Switzerland May 2005.

[13] Kassaye, K. D., Amberbir, A., Getachew, B., and Mussema, Y. (2006). Historical overview of traditional medicine practices and policy in Ethiopia. The Ethiopian Journal of Health Development, 30, 127-134.

[14] Alves, Romulo RN, and Rosa, Ierece ML. (2007). Biodiversity, traditional medicine and public health: where do they meet? Journal of Ethnobiology and Ethnomedicine, 3, 1-9. 
[15] Abebe D, Ayehu A. Medicinal Plants and Enigmatic Health Practices of North Ethiopia. Addis Ababa, Ethiopia: B. S. P. E; 1993.

[16] CBD (Convention on Biological Diversity). Forest and Aquatic Plants Genetic Resources. Addis Ababa: Institute of Biodiversity Conservation; 2008.

[17] Birhanu T, Abera D, Ejeta E. Ethnobotanical study of medicinal plants in selected Horro Gudurru Woredas, Western Ethiopia. Journal of Biology, Agriculture and Healthcare. 2015; 5 (1): 83-93.

[18] Bekele G, Reddy PR. Ethnobotanical study of medicinal plants used to treat human aliment by Guji Oromo tribes in Abaya district, Borena, Oromia, Ethiopia. University Journal of Plant Science. 2015; 3 (1): 1-8.

[19] Kelbessa E, Demissew S, Woldu Z, Edwards S. Some threatened endemic plants of Ethiopia. In: Edwards S, Zemede A, editors. The Status of Some Plants in Parts of Tropical Africa. NAPRECA, No. 2. East and Central Africa: Botany 2000; 1992. pp. 35-55.

[20] Asfaw Z. The role of home garden in production and conservation of medicinal plants. In: Zewdu M, Demissie A, editors. Conservation and Sustainable Use of Medicinal plants in Ethiopia. Proceeding of the National workshop on Biodiversity Conservation and Sustainable use of medicinal plants in Ethiopia; 28 April-01 May 1998. Addis Ababa: IBCR; 2001. pp. 76-91.

[21] Demissie A. Biodiversity conservation of medicinal plants: Problems and prospects. In: Zewdu M, Demissie A, editors. Conservation and Sustainable Use of Medicinal Plants in Ethiopia. Proceeding of the National Workshop on Biodiversity Conservation and Sustainable use of medicinal plants in Ethiopia, 28 April-01 May 1998. Addis Ababa: IBCR; 2001. pp. 56-64.

[22] Moges A, Beyene1 A, Triest L, Ambelu A, Kelbessa E. Imbalance of ecosystem services of wetlands and the perception of the local community towards their restoration and management in Jimma Highlands, Southwestern Ethiopia. Wetlands. Available from: https://doi.org/10.1007/ s13157016-0743.pdf [Accessed: 02 February 2019].

[23] Tolossa T, Megersa M. Ethnobotanical Study of Medicinal Plants Used to Treat Human Diseases in Berbere District, Bale Zone of Oromia Regional State, South East Ethiopia. London: Hindawi; 2018.2 Available from: https://doi.org/10.1155/2018/8602945. pdf [Accessed: 05 February 2019].

[24] Birhane E, Aynekulu E, Mekuria W, Endale D. Management, use and ecology of medicinal plants in the degraded dry lands of Tigray, Northern Ethiopia. Journal of Medicinal Plant Research. 2011; 5 (3): 309-318.

[25] Lianga YZ, Xieb P, Chanc K. Quality control of herbal medicines (Review). Journal of Chromatography B. 2004; 812: 53-70.

[26] Doffana ZD. Sacred natural sites, herbal medicine, medicinal plants and their conservation in Sidama, Ethiopia. Cogent Food and Agriculture. 2017; 3: 1365399. DOI: 10.1080/23311932.2017.1365399 [Accessed: 05 February 2019].

[27] Getnet Z, Chandrodyam S, Masresha G. Studies on traditional medicinal plants in ambagiorgis area of Wogera district,
Amhara regional state, Ethiopia. International Journal of Pure and Applied Bioscience. 2016; 4 (2): 38-45.

[28] WHO (World Health Organization). Quality Control Methods for Herbal Materials (Updated edition of Quality Control Methods for Medicinal Plant Materials published in 1998). Malta: WHO; 2011. 187 p. ISBN: 9789241500739.

[29] El-Alskary H. Quality control of herbal drugs: Total quality management of herbs and medicinal plants, and their products. In: Presentation on International Conference of Ministry of Agriculture and Land Reclamation; 6-8 December; 2011 [Accessed: 02 March 2019]. Available from: https://www.researchgate.net/publication/320306420.pdf [Accessed: 08 March 2019].

[30] Rajput R. Evaluation of Herbal Bioresources Using Histological and Histochemical Techniques. 2000. Available from: pdf.semanticscholar.org [Accessed: 14 March 2019].

[31] Guelmamene R, Bennoune O, Elgroud R. Histological techniques for quality control of meat and meat products-A mini-review. Journal of Nutrition and Human Health. 2018; 2 (2): 24-29.

[32] Oloyede, O., et al. (2011). Antioxidative Properties of Ethyl Acetate Fraction of Unripe Pulp of Carica papaya in Mice. Journal of Microbiology, 1, 409-425.

[33] Mirutse Giday et. Al (2006). Aklilu Lemma Institute of Pathobiology, P. O. Box 1176, Addis Ababa University, Addis Ababa, Ethiopia. Journal of Ethnopharmacology 110 (2007) 516-525.

[34] Poffenberger, M., McGean, B., Khare, A., Campbell, J., 1992. Field Method Manual, Volume II. Community Forest Economy and Use Pattern: Partici- patory and Rural Appraisal (PRA) Methods in South Gujarat India. Society for Promotion of Wastelands Development, New Delhi.

[35] Abebe, D., Ayehu, A., 1993. Medicinal Plants and Enigmatic Health Practices of Northern Ethiopia. B. S. P. E, Addis Ababa, Ethiopia.

[36] Trotter, R. T., Logan, M. H., 1986. Informants consensus: a new approach for identifying potentially effective medicinal plants. In: Etkin, N. L. (Ed.), Plants in Indigenous Medicine and Diet. Redgrave Publishing Company, Bedford Hill, NY, USA, pp. 91-112.

[37] Sorsa, S., 1992. In vitro evaluation of the activity of some Ethiopian traditional medicinal plants crude extracts against Plasmodium falciparum, MSc thesis, Addis Ababa University, Addis Ababa, Ethiopia.

[38] Oliver-Bever, B. O., 1986. Medicinal Plants in Tropical West Africa. Cambridge University Press, Cambridge.

[39] Desta, B., 1995. Ethiopian traditional herbal drugs. Part I: studies on the tox- icity and therapeutic activity of local taenicidal medications. Journal of Ethnopharmacology 45, 2733.

[40] Abebe, D., Hagos, E., 1991. Plants as a primary source of drugs in the tradi- tional health practices of Ethiopia. In: Engles, J. M. M., Hawkes, J. G., Melaku Worede (Eds.), Plant Genetic Resources of Ethiopia. Cambridge University Press, Cambridge, pp. 101-113. 